\title{
The Role of THE LAW in ACHIEVINg Sustainable URban DeVELOPMENT THROUGH FISCAL INCENTIVES IN NIGERIA*
}

\begin{abstract}
As the Nigerian population increasingly becomes urban, the situation has had harmful societal, environmental, health and infrastructural effects on the urban centres. The situation is exacerbated by the fact that the rate of land urbanisation in the country is moving at a slower pace, thereby placing pressure on the existing urban centres. Research conducted on urbanisation in Nigeria has revealed that the rate of urbanisation is unsustainable, serves as a constraint on economic development, and that Nigeria's cities are among the worst to live in. Meanwhile, Nigeria's population continues to increase and is expected to have doubled by 2050. It is against this backdrop that this paper undertakes a multidisciplinary study of how the law's adoption of fiscal incentives can help drive sustainable urban development in Nigeria. This paper argues that this will help the state governments in the decongestion of the existing urban centres (as the population urbanisation increases), ensure the creation of new urban centres, utilise fiscal incentives to attract businesses/ urban population to the new centres, and have sufficient fiscal revenues to sustainably manage the urban centres. This paper comparatively analyses the contribution of China's legal system to its state-led land urbanization moving at a faster rate than its population urbanisation, thereby avoiding the ills associated with urbanization such as congestion, unemployment, etc. With China and Nigeria sharing a similar decentralized tax and fiscal system, state ownership of land, and a large population, this paper argues that the Chinese model can be adopted successfully in Nigeria.
\end{abstract}

\footnotetext{
*Daniel Olika, Associate, Banwo \& Ighodalo. Contact: daniel_olika@yahoo.com.
} 
Key words: Urbanisation, Fiscal incentives, Decentralisation, Land urbanisation, Population urbanisation

\section{Résumé}

La population nigérienne est de plus en plus située en zones urbaines. Cette situation a des effets néfastes sur la société, l'environnement, la santé et les infrastructures des centres urbains. De surcroit, le fait que le taux d'urbanisation des terres dans le pays évolue à un rythme plus lent exacerbe une pression sur les centres urbains existants. Les recherches menées sur l'urbanisation du Nigeria ont révélé que le taux d'urbanisation est insoutenable, qu'il constitue une contrainte pour le développement économique et que les villes nigériennes offrent des conditions de vie plus que difficiles. Il faut ajouter à ces considérations un autre fait : la population du Nigeria devrait doubler d'ici 2050. C'est dans ce contexte que le présent document entreprend une étude multidisciplinaire sur la manière dont l'adoption d'incitations fiscales peut contribuer au développement urbain et durable du Nigeria. Cet article fait valoir que ces mesures incitatives pourraient permettre aux gouvernements des États de décongestionner les centres urbains existants, de créer de nouveaux centres urbains, d'attirer les entreprises et la population urbaine dans ces nouveaux centres et de disposer de recettes fiscales suffisantes pour gérer durablement les centres urbains. À des fins de comparaison, ce texte analyse également la contribution du système juridique chinois à une urbanisation des terres qui progresse plus rapidement que l'urbanisation de la population, évitant ainsi les maux associés à l'urbanisation comme la congestion et le chômage. La Chine et le Nigeria partageant plusieurs similarités (p. ex. : un système fiscal décentralisé similaire, des propriétés foncières étatiques et une population nombreuse), cet article soutient donc que le modèle chinois peut être adopté avec succès au Nigeria. 
Mots-clés : Urbanisation, mesures fiscales incitatives, décentralisation, urbanisation des terres, urbanisation de la population

\section{INTRODUCTION}

Nigeria, as a country, is no doubt becoming increasingly urbanized with a population growing rapidly at 3.2 percent per annum and is projected to double to an estimated 402 million people by 2050. ${ }^{1}$ Research shows that in the decade between 2007 and 2017, urban dwellers in Nigeria increased from 41 percent of the population to about 50 percent. ${ }^{2}$ In $2019,51.16$ percent of the country's total population lived in urban areas and cities. ${ }^{3}$ The crippling population boom in urban areas, coupled with the fact that rapid urbanization in the country is largely unplanned and uncoordinated, has inevitably created a state of urban decay replete with several societal, environmental, infrastructural and health crises. Today, the realities of life in Nigerian cities are extremely difficult, particularly in Lagos, where urbanization remains unsustainable and therefore manifests in different forms such as lack of basic facilities and infrastructure, inadequate solid waste and water management system, traffic congestion, housing shortage, proliferation of slums and shanty settlements, poverty, increased crime rates and other social vices. Rapid urbanization in Nigeria also manifests in the form of

\footnotetext{
1 VOA News, 'Nigeria's Population Projected to Double by 2050' (VOA News, 12 April 2019), $<$ www.voanews.com/africa/nigerias-population-projected-double-

2050\#: :text=Nigeria\%20has\%20the\%2olargest\%2opopulation,lack\%20of\%2ofamily\%2oplanning\% 20access. > accessed 1 May 2021.

${ }^{2}$ John Campbell, 'Home to Over Half the Population, Nigeria's Cities Continue to Boom' (CFR, 22 August 2019), <www.cfr.org/blog/home-over-half-population-nigerias-cities-continue-boom> accessed 1 May 2021.

3 Aaron O'Neill, 'Nigeria: Urbanization from 2009 to 2019' (Statista, 1 April 2021) $<$ www.statista.com/statistics/455904/urbanization-in-nigeria/> accessed 1 May 2021.
} 
environmental degradation and includes the loss of biodiversity, salinization of agricultural land, air and water pollution, desertification, environmental decay and so on, all of which adversely affects sustainable urban development in the country. 4

It is important to draw a distinction between land urbanisation and population urbanisation. Land urbanisation involves the transformation of rural land into urban land with a view to expanding the urban areas. It indicates the spatial or physical enlargement of urban built-up areas. Population urbanisation, on the other hand, involves the progressive or gradual transfer of the population from rural areas to cities. ${ }^{5}$ Indeed, there is an imbalance between population urbanization and land urbanization in Nigeria, as the latter moves at a slower pace than the former, thereby placing constraints on existing urban centers in the country. Accordingly, the 2018 Revision of World Urbanization Prospects notes that the size of the world's urban population is expected to increase in the future and be highly concentrated in just a few countries. Together, India, China and Nigeria will account for 35 percent of the projected growth of the world's urban population between 2018 and $2050 .{ }^{6}$ By 2050, it is projected that India will have added 416 million urban dwellers, China 255 million, and Nigeria 189 million. ${ }^{7}$ As the number of people living in towns and cities increases, existing

\footnotetext{
4 B Ogunleye, 'Environmental degradation control for sustainable urban growth in Nigeria' in Fadare et al (eds), Proceedings of the Conference on Globalization, Culture and the Nigerian Built Environment (Vol. II. Ile-Ife, Nigeria, 2005); See also, Muhammad Salisu, 'An Overview of Urbanization and its Challenges on Sustainable Development in Nigeria' (Research Gate, September 2015), $<$ www.researchgate.net/publication/318876748 AN OVERVIEW OF URBANIZATION AND ITS CHALLENGES_ON_SUSTAINABLE_DEVELOPMENT_IN_NIGERIA> accessed 1 May 2021.

5 See, Li Ji and Wei Zhang, 'Fiscal Incentives and Sustainable Urbanization: Evidence from China', (2020) 12 S 103, available at; <www.mdpi.com/2071-1050/12/1/103/pdf> accessed 1 May 2021. ${ }^{6}$ United Nations, ' $68 \%$ of the world population projected to live in urban areas by 2050, says UN' (UN, 16 May 2018) <www.un.org/development/desa/en/news/population/2018-revision-of-worldurbanization-prospects.html> accessed 1 May 2021.

7 ibid.
} 
urban infrastructure has proven inadequate in catering for the needs and increased demands of urban residents. ${ }^{8}$ This situation is further exacerbated by the unplanned and uncontrolled manner in which land urbanization in Nigeria is being carried out. ${ }^{9}$ Several studies have shown that the inadequate planning of urban land uses in the country and the intensity of use have contributed to the various urban problems and challenges. ${ }^{10}$ It has been reported that many cities in Nigeria are decaying without any plan for rehabilitation while new urban centres are being developed without adequate planning or necessary infrastructure. ${ }^{11}$

Considering their constitutional powers and functions, state governments are key actors in the strategic spatial planning processes required to address urbanisation in Nigeria, ${ }^{12}$ and to ensure that land urbanisation moves at a faster rate than population urbanisation through the utilisation of fiscal incentives, as is the case in China. This will be effective for the purpose of addressing the myriads of problems associated with urbanisation in the country, ensuring the creation of new urban centres and attracting businesses to the urban centres, while generating sufficient fiscal revenues to sustainably manage and develop the urban centres in the country. This paper therefore seeks to examine the role of the law in achieving

8 William Robert, 'Urban Expansion in Nigeria' (K4D, 29 October 2019), $<$ https://opendocs.ids.ac.uk/opendocs/bitstream/handle/20.500.12413/14797/692 Urban Expansi on of Nigerian Cities.pdf?sequence $=3$ \&isAllowed $=\mathrm{y}>$ accessed 1 May 2021.

9 The Cities Alliance, 'Foundation for Urban Development in Africa: The Legacy of Akin Mabogunje' (World Bank, 2007), Page 3.

<http://documents.worldbank.org/curated/en/482851468202163524/pdf/481540WPourban1oBox3 38889Bo1PUBLIC1.pdf $>$ accessed 1 May 2021.

${ }^{10}$ Adepoju Onibokun and Adetoye Faniran, 'Urbanization and Urban Problems in Nigeria' in Adepoju Onibokun and Adetoye Faniran, Urban Research in Nigeria (IFRA Nigeria, 1995) <https://books.openedition.org/ifra/544?lang=en> accessed 1 May 2021.

11 ibid.

${ }^{12} \mathrm{R}$ Bloch et al, 'Urbanisation and Urban Expansion in Nigeria' (2015), <http://urn.icfwebservices.com/Media/Default/Research\%20Reports/URN\%20Theme\%20A\%20Ur banisation\%20Report\%20FINAL.pdf> accessed 1 May 2021. 
sustainable urban development in Nigeria through fiscal incentives. The second part of this paper shall examine the various urbanization policies implemented in Nigeria and the nature of their impact. The third part assesses China's urbanization process and how its legal system has contributed to its state-led land urbanization moving at a faster pace than its population urbanization. The fourth part of this paper makes a case for achieving sustainable urbanization in Nigeria through fiscal incentives. The fifth and final part concludes this paper and makes recommendations on how fiscal incentives can be efficiently and effectively utilized by the state governments with a view of achieving sustainable urban development in the country.

\section{PART 1. AN OVERVIEW OF URBAN DEVELOPMENT POLICIES AND LAWS IN NIGERIA}

The Nigerian government in the past has initiated several policies and laws to address the issues of urban development in the country. The colonial period witnessed the implementation of several policies and laws to guide urban and regional development. The introduction of indirect rule in the country and the Land Promulgation of 1900 with respect to title to land in Northern Nigeria were major changes effected in land administration in Nigeria. ${ }^{13}$ The indirect rule policy created a system where urban settlements were administered by the native rulers while European quarters and Government Reservation Areas (GRAs), created pursuant to the Cantonment Proclamation of 1904, were administered by the colonial government. ${ }^{14}$ Different planning standards were specified for the various segments of the city while physical planning and provision of infrastructure were concentrated in the GRAs which were exclusively for the colonial population. The enactment of the Township Ordinance No. 29 of 1917 was however the first attempt at introducing spatial orderliness into the land use pattern in Nigerian cities.

\footnotetext{
${ }^{13}$ Felix Omole, 'Land Development and Planning Laws in Nigeria: The Historical Account' (2012) 8 JLPG 25 at $26<$ https://core.ac.uk/download/pdf/234649591.pdf $>$ accessed 1 May 2021. 14 ibid.
} 
The Ordinance laid down guidelines for physical layout of towns and its impacts are still visible today in towns such as Aba, Port Harcourt, Enugu, Jos, Minna, and Kaduna. ${ }^{15}$

The Lagos Town Planning Ordinance of 1928, which was subsequently enacted, established the Lagos Executive Development Board in response to the bubonic plague that broke out at that time. The Board was vested with the responsibilities of swamp reclamation, slum clearances, market planning and the development of suburban estates for African employees. ${ }^{16}$ The commencement of the systemic development plans was triggered by the preparation of a ten-year Plan of Development and Welfare (1946-1956) by senior government officials. The Governor-General's approval was required for giving effect to the decision of the Board. The Town Planning and Village Reconstruction was one of the projects identified in the plan. Available data from the plan showed that there was no town in the entire country that did not need to be revamped for expansion and development ${ }^{17}$ Consequently, the Nigeria Town and Country Planning Ordinance (No 4 of 1946) was enacted to provide for the planning and development of different parts of the country, through planning schemes initiated by planning authorities. The Ordinance was modelled after the 1932 British Town and Country Planning Act. ${ }^{18}$ The implementation of the Ordinance was however restricted to European residential areas and the Ordinance did not encourage integrated and participatory planning approaches. ${ }^{19}$ Other legislations on town and country planning during the colonial era include the 1945 Mineral Act which addresses issues relating to air and water pollution, the Land

15 ibid.

${ }^{16}$ RK Home, 'Town Planning, Segregation and Indirect Rule in Colonial Nigeria' (1983) 5 TWPR 165175 .

17 Omole (n 14).

${ }_{18}$ CS Ola, Town and Country Planning and Environmental Lands in Nigeria, (OUP 1984); FK Omole, 'Town Planning and the New Planning Order' in Headline, No 263, DTL Lagos, Nigeria 3-15.

19 VI Ogu, 'Evolutionary Dynamics of Urban Land Use Planning and Environmental Sustainability in Nigeria: Planning Perspectives’ (1999) 14(4) PP 347-368. 
Development (Roads) Law of 1948 which dwells on acquisition, safe disbursement of land, and the 1957 Public Health Laws which regulated over-crowding, diseases and general urban squalor. ${ }^{20}$

Upon independence, the Nigerian government initiated several national development plans and policies. The First National Development Plan (1962-1968) was mostly concerned with the rise of economic growth and per capita income of the country without due regard to the living conditions of the citizens..$^{21}$ The country was divided into three regions for effective spread of development and agriculture was given the highest priority, particularly in relation to the production of cash crops for export to the metropolitan countries. The plan was heavily dependent on foreign resources, transfer of technology and expertise in the planning and execution of major capital development projects, that is, as much as 50 percent of the total planned capital expenditure was expected from external sources. ${ }^{22}$ The First National Development Plan was not successful as a result of several factors such as the differences in values and ethnic affiliations coupled with the burning political tensions within the planned period and the fact that $42.8 \%$ of the estimated capital expenditure allocated to the agricultural sector was not spent due to the vocational problems of projects in the country. ${ }^{23}$ The Second National Development Plan (1970-1974) was launched shortly after the end of the civil war with the aim of reconstructing the facilities damaged by the war, creating effective administration of services especially in new states, improving the urban and rural areas and increasing the gross domestic product of the country. ${ }^{24}$ The plan aimed at a capital expenditure

\footnotetext{
${ }^{20}$ Omole (n 14).

21 ibid.

22 ibid.

23 ibid.

24 Muhammad Shehu, 'Trends and Nature of National Development Planning in Nigeria' (2020), $<$ www.researchgate.net/publication/346616615_Trends_And_Nature_of_National
} 
programme of $\mathrm{N}_{3.192}$ billion naira during the four years and this was expected to be distributed between the public and the private sectors. ${ }^{25}$ The huge investments in the various sectors of urban development were however largely uncoordinated and only about 7 percent of the total revenue allocated went into town and country planning (including housing, water and sewage). ${ }^{26}$ The major problems of the Second National Development Plan were lack of financial management, corruption, lack of will to perform task and dependency on a monocultural oil economy etc.

The Third National Development Plan (1975-1980) represents a watershed in the evolution of economic planning and urban development in Nigeria. The plan provided for integration of "urban-rural development, urban infrastructure, correction of physical planning inadequacies, reformation of local government machinery for efficient management of towns and cities responsibility and better involvement of states in urban matters." ${ }^{27}$ A federal ministry was created during this plan period which was responsible for housing and urban development. Notwithstanding the fact that there was financial robustness to implement the plan, there was lack of commitment and political inclination. The administration then was accused of corruption and having a lackadaisical attitude towards the implementation of the plan. ${ }^{28}$ The Fourth National Development Plan (1981-1985) was not entirely different from the Third National Development Plan. It was aimed towards establishing a solid base for the long-

\footnotetext{
_Development_Planning_in_Nigeria/link/5fc9ba42299bf188d4f1517b/download> accessed 1 May 2021.

25 Ibrahim Saadu, 'Second National Development Plan 1970-74' (Gco, 2 June 2017), <http://ibrahimgco.blogspot.com/2017/06/second-national-development-plan-1970-74.html> accessed 1 May 2021.

${ }^{26}$ Omole (n 14).

27 ibid.

${ }^{28}$ Shehu, (n 25).
} 
term economic and social development of Nigeria. ${ }^{29}$ Emphasis was placed on key sectors such as agriculture, manufacturing, education and manpower development, and infrastructural facilities. The plan recognized that regional and environmental planning was not fully entrenched in the planning and management of the urban and rural areas, and that the machinery for physical planning and administration was rudimentary. ${ }^{\circ 0}$ The Fifth National Development Plan (1986) was proposed with the aim of adjusting structural defects in the economy, diversifying the economy, revitalizing the agricultural sector and improving the living conditions and standards of the citizens. ${ }^{31}$ The plan however did not materialize in 1986 and was later incorporated into the Structural Adjustment Program (SAP). ${ }^{2}$ Several other policies and laws were put in place and these include the rolling plan of 1986 which was also adopted by the three tiers of government; the Land Use Decree of 1978, which later became the Land Use Act, designed to control the use of land and ensure equitable access to land by Nigerians; the creation of an Infrastructure Development Fund (IDF) in 1985 with the aid of the World Bank to finance urban development project; the 1991 National Housing policy which aimed to propose possible solutions to housing problems in Nigeria; the 1992 Nigerian Urban and Regional Planning Law which regulates physical and development planning in the country; the federal urban mass transit programme; the National Economic Empowerment and Development Strategy (NEEDS); the Nigerian vision 20:2020, the Transformation Agenda and the 7 point agenda.

29 Ibrahim Saadu, 'Forth National Development Plan (1981-85)' (Gco, 2 June 2017) <http://ibrahimgco.blogspot.com/2017/06/forth-national-development-plan-1981-85.html> accessed 1 May 2021.

30 Omole (n 14).

${ }^{31}$ Shehu (n 25).

32 ibid. 
Apart from the major urban development policies and laws discussed above, there are other recent initiatives developed in Nigeria, such as the National Integrated Infrastructure Plan (2014-2043), which identifies the key infrastructure bottlenecks impacting Nigeria's competitiveness and provides the capital allocation framework which identifies the required investments to develop infrastructure in Nigeria in line with the country's growth aspirations. 33 There is also the 2012 National Urban Development Policy which aims to:

promote a dynamic system of clearly defined urban settlements, which fosters sustainable economic growth, promotes efficient urban and regional planning and development, as well as ensures improved standard of living and well-being of all Nigerians. 34

In 2019, the Federal Government announced that a new policy document will replace the 2012 document. The document aims to harness the positive contributions of urbanisation in terms of socio-economic and environmental development. It also aims to facilitate efficient and balanced urban development, management, and good governance through urban planning and the provision of basic infrastructural services. ${ }^{35}$ The National Housing Policy was also revised in 2012 and it recognises the need for maintenance, proper planning of the environment and addressing urban renewal and slums upgrade, including the establishment

\footnotetext{
33 United Nations Human Settlement Programme, 'Habitat Country Programme Document Nigeria: 2015-2017' ( UN Habitat, 2015) <https://mirror.unhabitat.org/download/docs/13237_1_595875.pdf> accessed 1 May 2021.

34 ibid.

35 Chiedum Uwaegbulam, 'New Urban Development Policy Underway' (The Guardian, 2019) $<$ https://m.guardian.ng/property/urban-development/news-urban-development-policy-underway/> accessed 1 May 2021.
} 
of infrastructure in the areas. ${ }^{36}$ This housing policy is aimed at ensuring that all Nigerians own or have access to decent, safe and sanitary housing in healthy environments with sound infrastructural services at affordable cost and security of tenure. ${ }^{37}$

\section{PART 2. ASSESSING CHINA’S APPROACH IN ACHIEVING SUSTAINABLE URBANISATION}

Although China's urbanisation began almost 4,000 years ago, it has been observed that Neolithic villages had begun to appear in river valleys a thousand years before that. $3^{8}$ Urbanisation has moved at an unprecedented scale in China. In 2011, the urban population in the country reached 51.27 percent which was the first time that the urban population exceeded the rural population. 39 The total number of cities in China increased from 193 in 1978 to 660 in 2008, and its urban population rapidly increased from 172.45 million to 606.67 million. ${ }^{40}$ China's urbanisation process is no doubt succeeding, as it has largely avoided the common problems and challenges of urbanization, such as rising unemployment, crime rates, slums, and congestion..$^{41}$ The country's record of economic growth has succeeded in lifting half a billion people out of poverty while providing abundant labour, affordable land and good

${ }^{36}$ Taiwo Adeshina and Richard Idaeho, 'Analysis of Nigeria's Policies on Housing' (Jackson, Etti \&Edu, 2019) $<$ www.jacksonettiandedu.com/wp-content/uploads/2019/o1/Analysis-ofNigeria\%25E2\%2580\%2599s-Housing-Policies.pdf> accessed 1 May 2021.

37 United Nations Human Settlement Programme (n 34).

${ }^{88}$ The World Bank, 'China's Rapid Urbanization: Benefits, Challenges \& Strategies' (World Bank, gJune 2008) <www.worldbank.org/en/news/feature/2008/06/19/chinas-rapid-urbanization-benefitschallenges-strategies $>$ accessed 1 May 2021.

39 China National Bureau of Statistics, China Statistical Yearbook 2012, (China Statistical Press 2012). ${ }^{40} \mathrm{KY}$ Wu and H Zhang, 'Land Use Dynamics, Built-up Land Expansion Patterns, and Driving Forces Analysis of the Fast-growing Hangzhou Metropolitan Area, Eastern China (1978-2008)' (2012) 34 AG 137-145.

${ }^{41} \mathrm{Li}$ Ji and Wei Zhang (n 6). 
infrastructure to its population..$^{2}$ During the period from 2000 to 2009 , the urban area in China grew from 2.24 million hectares to 3.81 million hectares. 43 When compared to the annual urban population expansion rate of 3.6 percent, the annual urban land expansion rate is 6.2 percent per year which is an indication that land urbanisation moves at a faster rate than population urbanisation in China. 44 The remarkable success of urbanisation in China can therefore be attributed to increased urban lands, control of rural-urban migration and the implementation of a decentralised fiscal system which encourages local governments to compete for resources between cities. 45 In light of the specific conditions of China's household registration and land ownership system, the urbanisation pattern is dominated by local governments which play a pivotal role in accelerating the process of urbanisation in the country through local land finance or fiscal incentives..$^{46}$ Local land finances are local revenues that are generated out of land, either directly or indirectly, and include land leasing income, tax revenue generated directly from land use and development such as urban land-use tax, land value-added tax, and tax revenue generated indirectly from land use and development such as corporate tax and income tax paid by the housing and construction industries. ${ }^{47}$ Several Chinese scholars have agreed that fiscal revenues and fiscal incentives account for

42 The World Bank, 'Report Makes the Case for Market-Based Allocation of Land, People and Capital' (World Bank, 25 March 2014) <www.worldbank.org/en/news/press-release/2014/03/25/china-anew-approach-for-efficient-inclusive-sustainable-urbanization $>$ accessed 1 May 2021.

43 P Tang, L Zhou and X Shi, 'Factors Impacting Local Government Dependent on Land Finance According to Provincial-Level Panel Data from 1998 to 2010 in China' (2014) 36(7) RS 1374-1381.

$44 \mathrm{Li}$ Ji and Wei Zhang (n 6).

$45 \mathrm{C} \mathrm{Xu}$ and $\mathrm{Y}$ Qian, 'Why China's Economic Reforms Differ: The M-Form Hierarchy and Entry/Expansion of the Non-State Sector' (1993) 1 ET, 135-170; Y Qian and G Roland, 'Federalism and the Soft Budget Constraint' (1998) 88 AER, 1143-1162; C Xu, 'The Fundamental Institutions of China's Reforms and Development' (2011) 49 JEL 1076-1151.

${ }^{46} \mathrm{Li}$ Ji and Wei Zhang (n 6).

47 See GC Lin, 'China's Landed Urbanization: Neoliberalizing Politics, Land Commodification, and Municipal Finance in the Growth of Metropolises' (2014) 46 EPA 1814-1835. 
nearly 40 percent to 60 percent of the general budget revenue at the municipal level, thereby significantly contributing to the acceleration of economic growth and urbanisation level in China. .8

A cornerstone of China's urbanisation strategy has been the household registration (hukou) system and land ownership system. The household registration system classifies each person as a rural or an urban resident and is used as a major tool of controlling population mobility and determining eligibility for state-provided services and welfare. 49 The Chinese government believed that a large majority of the country's population should live and work in the rural areas, since these areas had the most opportunity to utilise labour. Moreover, it was felt that allowing citizens to move freely around the country could pose a threat to the agricultural output.50 Thus, strict restrictions were placed by the government on migration into the larger cities for the purpose of controlling population boom in the cities and preventing congestion, proliferation of slums and poor health conditions which may occur as a result of the rapidly growing population. ${ }^{51}$ In classifying its citizens into either urban or rural residents, the Chinese government required these two categories of the population to continue residing and working within their geographical locations. The rural hukou was assigned to residents who live in towns and villages while urban hukou was assigned to those who live in

${ }^{48}$ L Liu and Y Feng, 'Reform of the Financial System and Changes of the Local Finance: Under the Fiscal Federalism' (2010) 299 TR 12-17. See also, GC Lin and F Yi, 'Urbanization of Capital or Capitalization on Urban Land? Land Development and Local Public Finance in Urbanizing China' (2011) 32(1) UG 5079 .

49 Kam Wing Chan, 'The Household Registration System and Migrant Labor in China: Notes on a Debate' (New Horizon, 2010) 36(2) PDR, 357 <https://pubmed.ncbi.nlm.nih.gov/20734556/> accessed 1 May 2021.

50 Antoine Boquen, 'China's Hukou System Explained' (New Horizon, 11 March 2021), $<$ https://nhglobalpartners.com/the-chinese-hukou-system-explained/> accessed 1 May 2021. 51 ibid. 
larger cities. Although traveling was permitted, it was highly controlled and subjected to certain conditions. Illegal migrants were unable to gain access to basic facilities and services such as access to education, healthcare, employment, food services and other public services..$^{2}$ With the requirements and conditions implemented by the government relating to the issuance of hukou, acquiring one was highly difficult and this fact was worsened by the tight conversion quotas imposed by the government annually. .53

In 1984, the hukou system was reformed, allowing peasants and members of the lower class to enter market towns across the country. A new kind of permit was created during this period called the "self-supplied food grain" hukou which required residents, who intend to receive this permit, to work for a Chinese business, hold accommodations in the country and provide their own grain. Holders of this permit were not allowed to move to an area more urban than the location they resided at the time they acquired the permit.54 In the early 1990s, China launched another hukou permit called the "blue-stamp" which was available to a wider population and allowed residents to legally migrate to larger cities. These cities include China's Special Economic Zones, which are known as tax havens for foreign investors. This hukou permit is limited to residents with direct relations to local and foreign investors. 55 Since the late 1990s, the Chinese government has deepened and expanded prior hukou reforms. These efforts have occurred sporadically between 2001 and 2004 and have been followed by central directives to slow the pace of change. The reforms include streamlining hukou registration in

\footnotetext{
52 ibid.

53 ibid.

54 ibid.

55 ibid.
} 
some provinces and large cities and instituting many individual reforms aimed at addressing the abuse of migrants. ${ }^{6}$

The landownership system in China has also contributed to the process of land urbanisation moving faster than population urbanisation under the management of local governments. China has two types of land ownership, namely, state-owned urban land and farmer collective-owned rural land. The process of land urbanisation in China usually involves acquiring rural land by the government and converting it into urban land for development and transfer. After being expropriated by local governments, the former rural collective-owned land flows into the land primary market that is monopolised by local authorities. Local governments sell land use rights to developers for urban construction projects through public tender and auction at a market price.57 Once developers obtain the use-right to develop the newly converted urban state-owned land, they then pay relevant taxes to local governments, including land leasing fees, construction fees, and land-using tax, ${ }^{8}$ which will cover compensation for farmers and cost of newly built urban infrastructures.59 It is therefore not surprising to find that local governments have great fiscal incentives to change the rural collective-owned land into the urban state-owned land. Compared to the tax-free policy for agricultural use land in rural areas, revenues generated from urban state-owned land become the main source of local finance, since China's special land market tends to appreciate the value of urban state-owned land but depreciates the value of rural collective-owned land. In

\footnotetext{
${ }^{6}$ Congressional-Executive Commission on China (CECC), 'China's Household Registration System: Sustained Reform Needed to Protect China's Rural Migrants', <www.cecc.gov/publications/issuepapers/cecc-special-topic-paper-chinas-household-registration-system-sustained $>$ accessed 1 May 2021.

57 Lin and Yi (n 49).

${ }^{8} \mathrm{C}$ Ding, 'Land policy reform in China: assessment and prospects' (2003) 20 LUP 109-120. 59 ibid.
} 
2013, the revenue derived from land transfer was reported to have exceeded 670 billion dollars and accounted for 7.25 percent of the GDP, and 31.94 percent of the fiscal revenue. ${ }^{60}$ According to one estimate, residential property construction alone contributes to around 10 to 12 percent of the country's GDP. ${ }^{61}$

Research shows that in China, fiscal incentives have been a major drive of the local governments in promoting urbanisation in the country. To reduce the state fiscal capacity, the tax-sharing system has reduced the share of local governments' entitlement to several important tax sources. ${ }^{62}$ Due to the tax-sharing reform conducted by the Chinese government in 1994, 75 percent of the value-added tax (which is the largest tax in China) was turned over to the central government. Local governments lost $60 \%$ of their income tax revenue because of the income tax reform in 2002 and were therefore left with business tax which became the major source of local revenue and a driving force in local land urbanisation. Since tax revenue could not adequately satisfy the expenditure needs of local governments, the local governments began to seek extra budgetary income. ${ }^{63}$ Local authorities were therefore pushed to take on the role of land developers while using their exclusive power over land management to promote economic growth and meet the development targets. ${ }^{64}$ The promulgation of the Land Administration Law in 1998 allowed local governments to acquire, develop, and transfer

60 ibid.

${ }^{61}$ LH Ong, 'State-Led Urbanization in China: Skyscrapers, Land Revenue and Concentrated Villages' (2014) 27 TCQ 162-179.

${ }^{62} \mathrm{JK}$ Kung, $\mathrm{C} \mathrm{Xu}$, and $\mathrm{F}$ Zhou, 'From Industrialization to Urbanization: The Social Consequences of Changing Fiscal Incentives on Local Governments' Behavior' in D. Kennedy \& JE Stiglitz, Law and Economics with Chinese Characteristics (OUP 2013) 491.

${ }^{63}$ F Zhou, 'Land Finance and Local Government Behavior' (2010) 3 CESS 77-89; See also X Sun and F Zhou, 'Land Finance and Tax Sharing System: An Empirical Explanation' (2013) 4 SSC 40-59.

${ }^{64}$ E Lichtenberg and C Ding, 'Local Officials as Land Developers: Urban Spatial Expansion in China' (2009) 66 JUE 57-64. 
agricultural land and therefore provided an opportunity for the expansion of urban centres and the increase of fiscal revenues by local governments. ${ }^{65}$ Two main incentives for local officials to accelerate land urbanisation are revenue generation and investment attraction, and both of them are accompanied by GDP growth. ${ }^{66}$ By expanding the urban areas through rural land requisition, the local governments in China have obtained more fiscal revenue and have been able to achieve sustainable, efficient and inclusive urbanisation in the country.

PART 3. MAKING A CASE FOR ACHIEVING SUSTAINABLE URBAN DEVELOPMENT IN NigERIA

\section{THROUGH FISCAL INCENTIVES}

Nigeria is currently experiencing one of the fastest rates of urbanisation in the world and this urbanisation process has resulted in a very dense network of urban centres which constitutes a major problem to urban residents whose quality of life and living conditions have deteriorated considerably. ${ }^{67}$ Various studies have been carried out on the causes of rural-urban migration in Nigeria. Some of these studies show that factors responsible for voluntary ruralurban migration include urban job opportunities, better housing conditions, better education opportunities, better health services, extreme poverty, and so on. ${ }^{68}$ Other studies carried out

${ }^{65} \mathrm{Li} \mathrm{Ji}$ and Wei Zhang (n 6).

${ }^{66}$ Ying Qiu, 'The Role of Local Government in China's Urbanization: The Relationship Between Local Land Finance and Government-Led Urbanization' (2016) MPAMRP 148, <https://core.ac.uk/download/pdf/80537317.pdf> accessed 1 May 2021.

${ }^{67}$ Ajala, OA, "Environmental Impact of Urbanization: The challenges to urban governance in Nigeria" in, W Fadare, et al, eds, Proceedings of the Conference on Globalization, Culture and the Nigerian Built Environment, (2005) 2 Obafemi Awolowo University, Ile-Ife, Nigeria.

${ }^{68} \mathrm{KE}$ Johnson KE and U Ifeoma, 'Rural development as a panacea for rural-urban migration in Nigeria' (2018) 2(5) Arts \& Humanities Open Access Journal 241-244, $<$ https://medcraveonline.com/AHOAJ/rural-development-as-a-panacea-for-ruralndashurbanmigration-in-nigeria.html> accessed 1 May 2021; Zainab Gimba and Mustapha Kumshe, 'Causes and Effects of Rural-Urban Migration in Borno State: A Case Study of Maiduguri Metropolis' (2012) 1 (1) Asian Journal of Business and Management Sciences 168-172, <www.ajbms.org/articlepdf/ajbms 2011 1130.pdf $>$ accessed 1 May 2021. 
reveal that various factors could induce rural-urban migration such as crisis, ethno-religious conflicts and wars. ${ }^{69}$ A major developmental challenge facing Nigeria is how to cope with the increasing urbanisation and minimise its adverse consequences on the cities as well as the overall wellbeing of the people..$^{\circ}$ Despite efforts of the government at resolving the social ills associated with urbanisation in the country and ensuring sustainable urban development, current realities suggest that the goal of achieving sustainability in the country is yet to be realised. ${ }^{71}$ Rather than improving, the physical conditions of the cities continue to degenerate while investment in urban infrastructure, including housing, has failed to keep pace with the growing population..$^{2}$

Prior to the 1970s, while the Nigerian economy was dependent on agriculture, the rate of rural-urban migration was very low. Data shows that in 1952, 11 percent of the total population was classified as urban. However, between 1985 and 2002, the percentage of the population living in urban areas rose to 31 percent and 46 percent, respectively. ${ }^{73}$ The discovery of crude oil led to the increased migration of rural dwellers in the search of white-

69 Jacob Adewale, 'Socio-Economic Factors Associated with Urban-Rural Migration in Nigeria: A Case Study of Oyo State, Nigeria' (2005) 17(1) JHE, <www.researchgate.net/publication/267716974_SocioEconomic Factors Associated with Urban-

Rural Migration in Nigeria A Case Study of Oyo State Nigeria> accessed 1 May 2021. $7^{\circ}$ AD Jiboye, 'Achieving Sustainable Housing Development in Nigeria: A Critical Challenge to Governance' (2011) 1(9) IJHSS 121-127.

${ }^{71} \mathrm{AD}$ Jiboye, 'Sustainable Urbanization: Issues and Challenges for Effective Urban Governance in Nigeria' (2011) 4(6) JSD, <www.researchgate.net/profile/AdesojiJiboye/publication/269670429 Sustainable_Urbanization_Issues and Challenges for_Effective_U rban_Governance in Nigeria/links/54d9d6c50cf24647581f9o8a/Sustainable-Urbanization-Issuesand-Challenges-for-Effective-Urban-Governance-in-Nigeria.pdf $>$ accessed 1 May 2021. ${ }^{72}$ AD Jiboye, 'The Challenges of Sustainable Housing and Urban Development in Nigeria' (2009) 4(3) JERP 23-27.

73 TP Ogun, 'Infrastructure and Poverty Reduction: Implications for Urban Development in Nigeria' (2010) 21(3) UF 249-266. 
collar jobs. Though this period saw an increased investment in infrastructure and economic expansion, the rate of these expansions fell below the level needed to support the population in urban centres like Lagos, Kaduna, Kano and Port Harcourt. ${ }^{74}$ This migration and the resultant urbanisation have brought about a variety of problems such as extreme crime rates, high unemployment, high poverty rate, slums, insecurity and economic degradation. ${ }^{75}$ Thus, the failure of the government to efficiently expand the current urban centres and create new ones has inevitably created a state of congestion in the cities due to the rapidly growing population.

As land urbanisation continues to move at a slower pace than population urbanisation in Nigeria, the standard of living in existing urban centres deteriorates, thereby creating many challenges of urbanisation in the country. These challenges are further exacerbated by a concentration of resources in urban centres, continued migration of resources from rural areas to urban areas, lack of adequate long-term planning for the development of cities and rural areas, and a lack of continuity in the planning and implementation process. ${ }^{76}$ The importance of investing in land urbanization can therefore not be overemphasized. It has been noted that rapid urban growth and expansion necessitates the need to provide utilities and road networks alongside services such as schools, recreational parks, healthcare, and retail parks. ${ }^{77}$ There is no doubt that the growth of these cities leads to megacities, which in turn creates industries that provide locally made products, job opportunities and extra tax revenue..$^{8}$ The expansion

\footnotetext{
74 Job Momoh et al, 'Challenges facing Nigeria's Urban Environment: The Abuja Case' (2018) 20(2) JSDA,

$<$ https://openresearch.Isbu.ac.uk/download/182704/CHALLENGES_FACING_NIGERIAS_URBAN

ENVIRON.pdf $>$ accessed 1 May 2021.

75 T Agbola, Readings in Urban and Rural Planning, (Macmillan Nigeria 2004).

${ }^{76}$ Momoh (n. 75).

77 ibid.

78 ibid.
} 
of cities helps in advancing urban development projects and creates provision of public facilities.79 Furthermore, land urbanisation attracts large volumes of highly skilled labour based on the influx of people in search of better jobs and there is a high concentration of capital stock which makes the urban centres attractive for investment. ${ }^{80}$ It is therefore imperative for the Nigerian government to utilise fiscal incentives as a solution towards achieving sustainable urbanisation in the country while ensuring that land urbanisation moves at a faster pace than population urbanisation as in the case of China.

Nigeria operates a system of fiscal decentralisation, with the legislative powers of the various levels contained in the Second Schedule of the 1999 Constitution. Some of these legislative powers are exclusively vested in the Federal Government by virtue of the exclusive legislative list while others are shared between the Federal and State Governments in accordance with the concurrent legislative list. Until 2003, it had been widely accepted that it was within the legislative competence of the Federal Government to enact laws for the States on urban planning and the Nigerian Urban and Regional Planning Act (NURPA) was introduced for this purpose. ${ }^{81}$ However, after the decision of the Supreme Court in A.G. Lagos State v A.G. Federation, ${ }^{82}$ it was settled that the Federal Government cannot legislate for any of the 36 States on urban planning and to the extent that NURPA claimed to do so, its provisions were void and unconstitutional, although they would still remain applicable to the Federal Capital Territory (FCT), which is under the direct administration of the Federal Government. According to the Supreme Court, any matter not mentioned in either the

\footnotetext{
79 Kotter Theo, 'Risks and Opportunities of urbanization and megacities PS2 Plenary session 2-Risk and Disaster Prevention and Management' (2004) FWW.

80 Momoh (n 75).

${ }^{81}$ Bola Fajemirokun, 'Policy and Legal Perspectives on Actualizing the Right to the City in Nigeria' (2009), < www.citego.org/bdf fiche-document-1468 en.html > accessed 1 May 2021.

82 (2004) 18 NWLR (Pt. 904) 1.
} 
exclusive or concurrent legislative list becomes a residual matter exclusively for the State Houses of Assembly by virtue of Section 4(7), and a residual matter exclusively for the National Assembly regarding the FCT by virtue of Section 299 of the 1999 Constitution. This decision effectively displaced any centralised national planning of cities and has led to the entrenchment of local planning autonomy even in respect of federal government-owned land. ${ }^{83}$

It is ideal that under a federation, each tier of government, whether federal, state or local, should be assigned taxing powers to raise sufficient revenue to conduct its operations and no government should rely on another government for a significant portion of its revenue. ${ }^{84}$ The problem, however, with Nigeria's fiscal federalism is that the state and local Governments heavily rely on revenue allocated from the federation account, ${ }^{85}$ while the taxing and spending powers are disproportionately in favour of the Federal Government, despite the recent tax reforms and constitutional amendments. ${ }^{86}$ Nigeria, therefore, does not operate a true fiscal federalism as the federal government still gets 52.68 percent of the total revenue without corresponding responsibilities while leaving the 36 states and 774 local governments with 26.72 percent and 20.60 percent respectively, with the 13 percent derivation revenue going to the oil producing states. ${ }^{87}$ It has been observed that in terms of revenue assignment,

\footnotetext{
83 Fajemirokun (n 82).

84 Richard A Onuigbo and Okechukwu Eme, 'State Governors and Revenue Allocation Formular in Nigeria: A Case of the Fourth Republic' (2015) 2(7) IJAR, $<$ www.researchgate.net/publication/302453311 State Governors and Revenue Allocation Formu lar_in_Nigeria_A Case_of the_Fourth_Republic/link/57fao84108ae280ddobddab5/download> accessed 1 May 2021.

85 ibid.

${ }^{86}$ Adeleke Salami, 'Taxation, Revenue Allocation and Fiscal Federalism in Nigeria: Issues, Challenges and Policy Options' (2011) 189 EA, <https://core.ac.uk/download/pdf/27238465.pdf > accessed 1 May 2021.

87 Onuigbo and Eme (n 85).
} 
the fiscal system in Nigeria grants minimal fiscal autonomy to the states and local governments. ${ }^{88}$ For instance, all broad-based taxes such as company income tax, value-added tax (VAT), customs and excise duties, tax on petroleum products and education tax are assigned to the federal government. Consequently, the states and local governments make no serious efforts to generate revenue internally because of their dependence on the allocation from the federally generated revenue. ${ }^{89}$

Compared to population urbanisation that is less related to economic development, land urbanisation would no doubt drive improvement in revenue and investment, along with a higher GDP in a short period for Nigeria. ${ }^{\circ 0}$ The pivotal role of the state governments in accelerating land urbanisation in the country can therefore not be overemphasized. Since the driving forces of urbanisation include industrialisation, modernisation, marketisation and economic growth and development, it is imperative for the state governments to actively participate in diversifying the economy to foster economic activity within the states. The exclusive legislative list indicates areas in which the federal government holds an exclusive mandate in relation to agriculture, which are regulation of international trade in agricultural commodities and regulation of fishing in non-inland waters. Under the concurrent list, both the federal and the state governments engage in the establishment of agricultural research centers and establishment of institutions for the promotion and financing of agricultural

\footnotetext{
${ }^{88}$ FO Odoko and Nnanna, Fiscal Federalism Fiscal Discipline and Service Delivery in Nigeria, (Snaap Ltd, 2009)

${ }^{89}$ S Aigbepue and Ainabor Augustine, 'Issues and Challenges of Nigerian Federal Fiscalism' (2011) 1(10) IJRB 26-31, $<$ https://citeseerx.ist.psu.edu/viewdoc/download\%3Fdoi\%3D10.1.1.736.1310\%26rep\%3Drep1\%26typ e\%3Dpdf $>$ accessed 1 May 2021.

90 This is premised on the fact that empirical study of the impact of urbanization shows that it plays a role in economic growth and development. See, Mingxing Chen et al, 'The Global Pattern of Urbanization and Economic Growth: Evidence from the Last Three Decades,' (2014) 9(8) PlosOne 7.
} 
projects. In addition, both the federal government and the state governments are empowered to undertake any other activities that contribute to the agricultural development of each state. ${ }^{11}$ According to the 1999 Constitution, state governments do not hold any exclusive responsibilities when it comes to the provision of agricultural goods and services. The responsibilities of the state governments are stated only in the concurrent list, meaning that the state governments share their responsibilities and their powers with the other tiers of government. It is therefore necessary that agricultural policies, laws, and regulations stipulate what is concretely within the states' domain, as opposed to the federal government's domain. ${ }^{92}$ By investing in agriculture, for example, state governments can drive economic activity within the states, while increasing their revenue and achieving sustainable urban development in the country. Diversification of the economy through agriculture has the potential of resolving economic recession, unemployment problems, poverty and improving economic growth. 93 Responsible for over 75 percent of the growth in the non-oil sector, agriculture occupies a priority standing as a key driver of economic growth, wealth formation, revenue generation and sustainable development.94 Resuscitation of the agricultural sector will no doubt

\footnotetext{
91 'Agricultural Public $\quad$ Spending in Nigeria'

<https://ebrary.ifpri.org/digital/api/collection/p15738coll2/id/13548/download> accessed 1 May 2021.

92 ibid.

93 Joseph Tonuchi and Nwankwegu Onyebuchi, 'Economic diversification in Nigeria: The Role of Agriculture and Manufacturing Sector Joseph' (2019), $<$ www.researchgate.net/publication/337021801_Economic diversification in Nigeria The Role o f Agriculture and Manufacturing Sector> accessed 1 May 2021.

$94 \mathrm{GBAF}$, 'Optimizing the benefits of agriculture to transform Nigeria' Global Banking \& Finance Review <www.globalbankingandfinance.com/optimizing-the-benefits-of-agriculture-to-transform-nigeria/> accessed 1 May 2021.
} 
contribute immensely in reducing rural-urban migration and minimise the challenges that plague the urban centers. 95

The central thrust of the argument here is that, investment in agriculture can help to ensure that there is substantial economic activity in the rural areas to limit rural - urban migration (as was the case in the first republic). For this to be good policy within the context of this paper, then the regional governments must ensure that investment in agriculture is not threatened by governmental policy to drive land urbanisation. The analysis of the Chinese situation reveals that both policies were carried out simultaneously by the regional governments. Potency for this argument lies in the fact that improving the economic situation in the rural areas (through the proposed investment in agriculture) will be crucial to both limiting rural urban migration and also ensuring that the land urbanization also leads to the movement of people to the rural areas (inevitably decongesting the existing overpopulated urban areas).

Furthermore, amongst the taxes and levies collected by the state government, the land use charge can be utilised to increase the generation of internal revenue for financing public spending in agriculture. According to the Lagos State Land Use Charge 2018, land use charge includes all property, land-based rates, and charges payable under the Land Rates Law, the Neighbourhood Improvement Charge Law and Tenement Rates Law as may be computed under the law. The migration of people from the rural areas into cities such as Lagos, Abuja, and Port Harcourt no doubt imposes adverse challenges on the available infrastructures, whereas, funds allocated for improvements in these areas are far from sufficient for managing them. ${ }^{96}$ By increasing internally generated revenue bases through various forms of taxes on

95 ibid.

${ }^{96}$ Adebayo Michael Adedayo and Arimoro Theresa, 'Administration of Land use Charge in Lagos State, Nigeria' (2018)

$6(1)$

CJRBE, 
land and landed properties in the existing urban centres, state governments in Nigeria can invest in the existing urban centres, ensure the creation of new urban centres, utilise fiscal incentives to attract businesses and the urban population to the new centres, thereby reducing congestion in the cities.

\section{CONCLUSIONS AND RECOMMENDATIONS}

Urbanisation in Nigeria is no doubt demographically driven in the absence of commensurate socio-economic dividends and benefits to the urban environment and the existing urban centres. The current realities in Nigerian cities show that while the population becomes increasing urban, land urbanisation in the country keeps lagging in the urbanisation process. This rate of urbanisation is therefore unsustainable, as the current urban centres suffer from congestion because they are not dense with economic activity, infrastructure, or housing and commercial structures. To address the issue of unsustainable urbanisation, it is necessary for Nigeria to ensure that its land urbanisation moves faster than its population urbanisation through the state governments in the country. With China and Nigeria sharing a similar fiscal decentralization system, state ownership of land, and a growing population, it is argued that the Chinese approach of sustainable urbanisation can be adopted in Nigeria successfully. In achieving sustainable urban development in the country, the role of the state government is paramount.

The first step in achieving this will be for the state governments to drive the creation of sustainable urbanisation policies within their states. The states' urbanisation masterplan should be created with clear targets and monitored for success. The urbanisation policy should

$<$ https://journals.covenantuniversity.edu.ng/index.php/cjrbe/article/download/939/613>accessed 1 May 2021. 
place premium on driving land urbanisation at a faster pace than population urbanisation. This can only be achieved by ensuring that the economy in the rural centres is thriving to keep its population in place. The proven and sustainable way to achieve this is by driving a sustainable policy for agricultural development. 97 Putting the state in charge will ensure that land use policies are pro-agriculture and that land (which is in the exclusive control of the state government) is used to attract investments into the state. Large expanse of land belonging to the state can be used to drive agriculture by giving same to developers or farmers on terms favourable to the state for the purpose of land development through land financing. By attracting land developers to develop state land, granting state land in rural areas to farmers on concessionary basis for agriculture, and using land use charge to create incentives; the state can take charge of urbanisation policy in the way the regional governments have done in China. Deliberate efforts to ensure that investment in land urbanisation and agriculture is carried out against the backdrop of efficient use of land. To be effective, government must play a more critical role in regulating land use as the existing legal and constitutional framework in Nigeria vest regulation and control of land use in the state governor. This will have the effect of ensuring that land urbanisation moves faster than population urbanisation, create an incentive for people to move to rural areas since the agricultural sector will be booming ${ }^{98}$ and create more urban centres.

\footnotetext{
97 As noted in the previous section, governments must be deliberate to ensure that the losses suffered to agricultural lands following land urbanization are minimal, while also driving investment in agriculture. See, Christpher Bren d'amour et al, 'Future Urban Land Expansion and Implications for Global Croplands,' (PNAS, 2016) < https://www.pnas.org/content/pnas/114/34/8939.full.pdf > accessed 15 July 2021.

${ }^{98} \mathrm{~A}$ similar approach of prioritizing agriculture in the $60 \mathrm{~s}$ had a similar effect of creating economic activity in the rural areas and ensuring that the rate of rural to urban migration was low.
} 
Prioritising agriculture as part of its urbanisation policy also has the effect of contributing to diversification of the economy. This improves the state's GDP, improves taxable revenue, decongests the urban areas as economic opportunity accounts greatly for rural-urban migration in Nigeria. 